\title{
Brief Discussion on Absence and Treatment of Contemporary College Students' Honesty
}

\author{
Yang Yang \\ Department of Political Theory Education \\ Nanyang Institute of Technology \\ Nanyang, China
}

\begin{abstract}
Honesty is the basic requirement of strengthening the construction of civic virtues and the focus of the ideological and moral education. But dishonest phenomenon usually occurs in society at present. The college students in this environment inevitably have been affected. At the base of deep analysis for the present situation of traditional honesty education mechanism, put forward innovative thinking from various perspectives for college students' honesty education, in order to continuously improve the quality of college students' honesty education.
\end{abstract}

\section{Keywords-College student; Honesty; Education Mechanism}

Honesty is traffic permit of college students to enter society. The market economy needs the honest and trustworthy, abide by the contract of economic subject. Democracy and the legal system needs law-abiding an mutual trust of social members. College students, as the driving force for the future society, must stick to honesty, in order to be highly qualified talents and assume social responsibility and historical mission. At present, in overall college students' honesty situation is in good, however, there are a few college students' honesty situation is worrying.

\section{DishONESTY PHENOMENON OF COLLEGE STUDENT AT PRESENT}

\section{A. The embarrassed circumstances of state loan for student}

In view of economic difficulty of poor students, the Chinese government solemnly promises that there isn't any dropout student because of poverty. As the result, the national student loan is a loan on credit that is promoted by the central and provincial governments to help the undergraduate students, students and graduate students from full-time colleges at the aspects of tuition fees and daily life.

In 2012, according to a statistics from Guizhou province, the loan default of state loan for student is as high as $27 \%$, is higher than the non-performing loan ratio of enterprise, individual and industrial and commercial institutions.

There are many reasons for this problem, the current university students' employment difficulties results in lack of loan repayment ability. But maybe there are some students deliberately refuse repayment that leads to bad consequences. Student loan single amount is small, but the number of students involved is big, so the economic benefits of bank is not obvious. For Banks, if can't get effective compensation costs, their initiative of lend will inevitably be affect. Under the limited finance condition of the national, if a vicious circle is formed, the system performing difficulty will present inevitably, then it will make more people lose proper institutional guarantee.

\section{B. Cheating continuing in spite of repeated prohibitions}

At present, the characteristics of college students' cheating presented: First, the number of cheating students has been growing that becomes a mass incident. Second, the mentality of cheating has been becoming brazenly and calmly from surreptitiously. Three, the cheating methods has been emerging in endlessly, and the cheating tools have been becoming modernization. Four, "professional cheating people" have been appearing for the purpose of money in some areas. The behavior of dishonest to cheat in the exam is not only responsible for themselves, but also for the society or the parents.

\section{Academic faking}

There are cheating phenomenon usually in investigate paper, thesis or survey report.

\section{Employment cheating}

Employment cheat is mean exaggerated resumes by themselves and breaking or changing contract arbitrarily. At present, university students' employment difficult has been a common phenomenon, which has both social factors and factors of college students themselves. It can't be long lasting that find a better job for yourself with arbitrarily breaking contract. Employment is two-way behavior, therefore, the honesty should been held by both employer and employee.

\section{E. Internet moral disorder}

Internet has been an important method of communication at present, which of virtuality has contributed to the dishonesty. The dissemination of false news and false malicious unwarranted attack to someone both are dishonesty phenomenon in network.

\section{REASON ANALYSIS FOR DISHONESTY OF COLLEGE STUDENT}

\section{A. Values tend to pluralism, but utilitarianism}

College Students' value system has formed and developed that influenced during market economic system gradually establishing. Market economy pays attention to improve efficiency, at the same time, also easily leads people 
utilitarianism. Especially some dishonesty phenomena in the process of the market economic system and the sensitive experience and high absorption of university student to the network lead to collapse of old values system and construction of new values system ${ }^{[1]}$. Meanwhile their way of life and values also had a strong impact on the society. These complex factors have caused the problems of College Students' ideal, belief and moral quality, psychological quality etc. Therefore, utilitarian tendency of behavior choice has appeared while pay attention to personal development.

\section{B. Higher cognitive levels of honesty, honesty behavior anomie}

College students have correct understanding for the right and wrong to society. The vast majority of college students have higher expectation on honesty, and they likely connect honesty with personal quality, also hope that the society is a honest society. However in real life, their honesty cognition and honesty behavior has been disconnected each other, practical and utilitarian tendency will be obvious when immediate interests appear. For example that some students cannot implement the honesty cognition in their real life and studying, therefore cheating, plagiarism, malicious arrears of tuition fees, and even acts of theft have occurred from time to time. Honesty is the unity of cognition and behavior, it cultivates people with consciously controlling their own behavior according to certain principles. If honesty cognition hasn't internalized into self-discipline behavior, the trust behavior will lose.

\section{Lag of honesty evaluation system, lack of punishment}

Honesty crisis exists objectively in university students, which mainly owes to the pollution of social environment. Due to the lack and imperfect of social system rules, people behavior can't be regulated so that the honesty people can't get encourage, yet the dishonesty people haven't receive punishment and condemnation. A loophole in the internal management of colleges and universities, especially in some departments of close relationship with students, often make some students destroy the principle of honesty to reach their own purposes who have lucky psychology or see the immediate interests merely.

\section{THE SIGNIFICANCE OF STRENGTHENING HONESTY EDUCATION OF COLLEGE STUDENTS}

\section{A. Honesty is the basic condition of social harmony}

Honesty is the basic condition of social harmony, is the thermometer measures the degree of social harmony. It has great irreplaceable value whether in political life, economic activities, people's livelihood, or interpersonal communication. It is the external support that perfects socialist market economy system and promotes the construction of the social honesty system, also it is the safeguard of international communication and competitive. Without honesty, all social activities will be in a disorder state, which is bad for social civilization and progress. Therefore, honesty exist all places of human existence.

\section{B. Honesty is one of the basic characteristics of socialist harmonious society}

The basic requirement of harmonious relationship between people is honest, which is the ethics and behavior norms abide by all social members during constructing harmonious socialist society with the basic characteristics of the democracy and legal system, fairness and justice, honesty and friendship, full of vitality, stability and order, harmony between man and nature. A dishonesty society isn't a harmony society at all. It is necessary to develop the principle of honesty in order to form a spiritual bond to maintain social harmony and moral basis.

\section{Honesty is a necessary quality of Contemporary College Students}

Honesty is the social requirement and the own necessary quality. As one of the basic elements and norms of interpersonal communication and social development, honesty has an irreplaceable role in the construction of the socialist harmonious society. Contemporary college students should understand the harm and adverse of dishonesty, take honesty as its own rule of behavior in their studying, working, life and communication. Therefore, it is not only an important guarantee for the healthy growth of university students but also long-term task faced by college students to strengthen honesty cultivation of college students.

\section{CONSTRUCTION OF HONESTY EDUCATION SYSTEM}

\section{A. Honesty education of college students should pay equal attention to moral education and legal education}

Honesty is the human differ from animals and one of the most important symbols of civilization, is the important factors have moral personality. Therefore, the students should be educated to understand the honesty is the basic moral quality and virtue. Meanwhile, they should be educated with legal consciousness to make them abide by the laws, regulations and school rules and understand the law value of honesty. In particular, college students should learn the regulation of our country law about honesty according to various ways. Along with the development of the society, people have more and more requirement for honesty. Now many countries in the world not only write honesty requirement in civil law, commercial law, company law and other legal provisions, but also establish and improve the honesty rules system in order to realize these specifications of law. China not only has established the basic principle of honesty in the civil law, but also established the requirement of economic credit, administration credit, judiciary credit in different angles in the "Consumer Protection Law", "Civil Law", "Criminal Law" [2]. So the university should pay attention to the typical case teaching, court hearings, classroom discussion and other ways, make the students learn more about the legal system of honesty, make them aware that honesty is not only the moral requirement but also the legal requirement, and some dishonesty behavior is not only illegal behavior, even a crime. On this basis, college students should be educated in moral and legal with the whole society enthusiasm. 


\section{B. Construction of educational guidance and direction of public opinion mechanism}

Good quality of honesty of university students needs guiding and constructing correctly and a good social and cultural environment. If the whole society has high honesty, so students can easily form honesty character. The success because of dishonest behavior has bad influence on students' honesty values. Traditional education require honesty, while in real life many success resulted by dishonesty, this contrast between ideal and reality will increase dishonesty phenomenon. So a good honesty environment should be established. The honesty education should be taken into school education system including honesty moral education, honesty legal education and honesty economic education. Clear connotation of traditional and modern honesty, understand the social value and economic value of honesty and the important role of the market economy. Honesty advertisement should be taken using of newspapers, radio, television, Internet and other kinds of media. Colorful campus culture activities should be carried out to improve the moral level of college students and establish honest campus environment. During establishing the honest campus environment, the honest students should be praised, and the dishonest students should be condemned by full using of the role of social campus news media, public opinion. Cheating, plagiarism, and gaining allowance by cheating are evil trick. The media exposure is an effective way to punish the dishonesty behavior.

\section{Construction of reward for honesty and punishment mechanism for dishonesty}

If someone broke a window glass and is not punished, others may be indulgent to break more windows, which is the "broken window theory" from American political scientist Wilson and criminologist Kailin. This theory has important implications for disciplinary integrity environment and discreditable behavior. If a dishonest person did not receive due punishment, it is easy to make others follow and gradually led to the lack of overall credit environment. Therefore, at the same time of rewarding for honesty, the dishonesty should be punished more strictly to establish a strict punishment mechanism, which is the key to realize the optimizing credit environment. In order to construct honesty reward and punishment mechanism, firstly we should establish and perfect the rules and regulations, provisions of the rigid legal system to make students know under what conditions, under what circumstances, what to do, what not to do, or what must be done, otherwise they will bear the consequences for themselves' actions. Promote the formation of integrity quality of college students by using the law. Secondly, standardize the rewards and disciplinary procedures, focus on the fairness of system. In order to make the honesty principle is operable, the rewards and disciplinary procedures should be standardized to protect the legitimate rights of the students and also demonstrate the objectivity and fairness of rules and regulations

\section{Establishing a effective system of evaluation and supervision of College Students' honesty}

Honesty education cannot do without some institutional constraint. An effective restraint mechanism can be carried out by construction of credit evaluation system, making evaluation factors, indicators and standards, the establishment of individual credit archives for college students. It is not enough that only the evaluation mechanism is carried out, and the effective supervision system should be established to limit College Students' honesty consciousness and behavior. A supervision department should be established by the college to take supervision for the honesty system which is full process and full range, involving all aspects of student self-assessment, peer assessment, counselors review, personal data records; through advantages of the supervision of public opinion, supervision of institution, supervision of behavior and other modes, we can achieve the formation of a full range of supervision, restrain the behavior of students, which can formed the good faith consciousness and behavior from the heart. Additionally, except of the supervision, a reward and punishment mechanism should be established to make the supervision in earnest. For example, the students with low integrity index should sign honesty guarantee, increase the education, connect with the incentives, loan and employment, and limit its assessment, awarding authority. However the students with a high degree of credibility can be actively recommend to the development of Party branch, and to the employer.

\section{CONCLUSION}

College students are the future of our country and nation, the banner of high-level intellectuals in the society, the elite of the society, and are indispensible for the prosperity of our country and nation renaissance. Their position is so important, so that they can be positioned of the motherland flowers and the power of the nation renaissance. The future of the country should be a unity, friendship, and the society people can trust each other, that need College Students who are the constructer of our country to hard work. Therefore, every student should strengthen moral self-cultivation, pay attention to the honesty building, so as to the country can be promoted toward a better direction.

\section{REFERENCES}

[1] Feng shuangpeng: Study on the Model of Ideological and Political Education of Vocational College Students in the New Period [M],Northeastern University Press, Shengyang.

[2] He Jie: Legal approach to the prestige of university students $[\mathrm{J}]$. Journal of Nanjing University of Science and Technology, 2006, (2). 